(1) norden

\title{
GENDER MAINSTREAMING IN THE WORK PERFORMED BY MUNICIPALITIES
}

- Results and recommendations from a trans-Nordic study

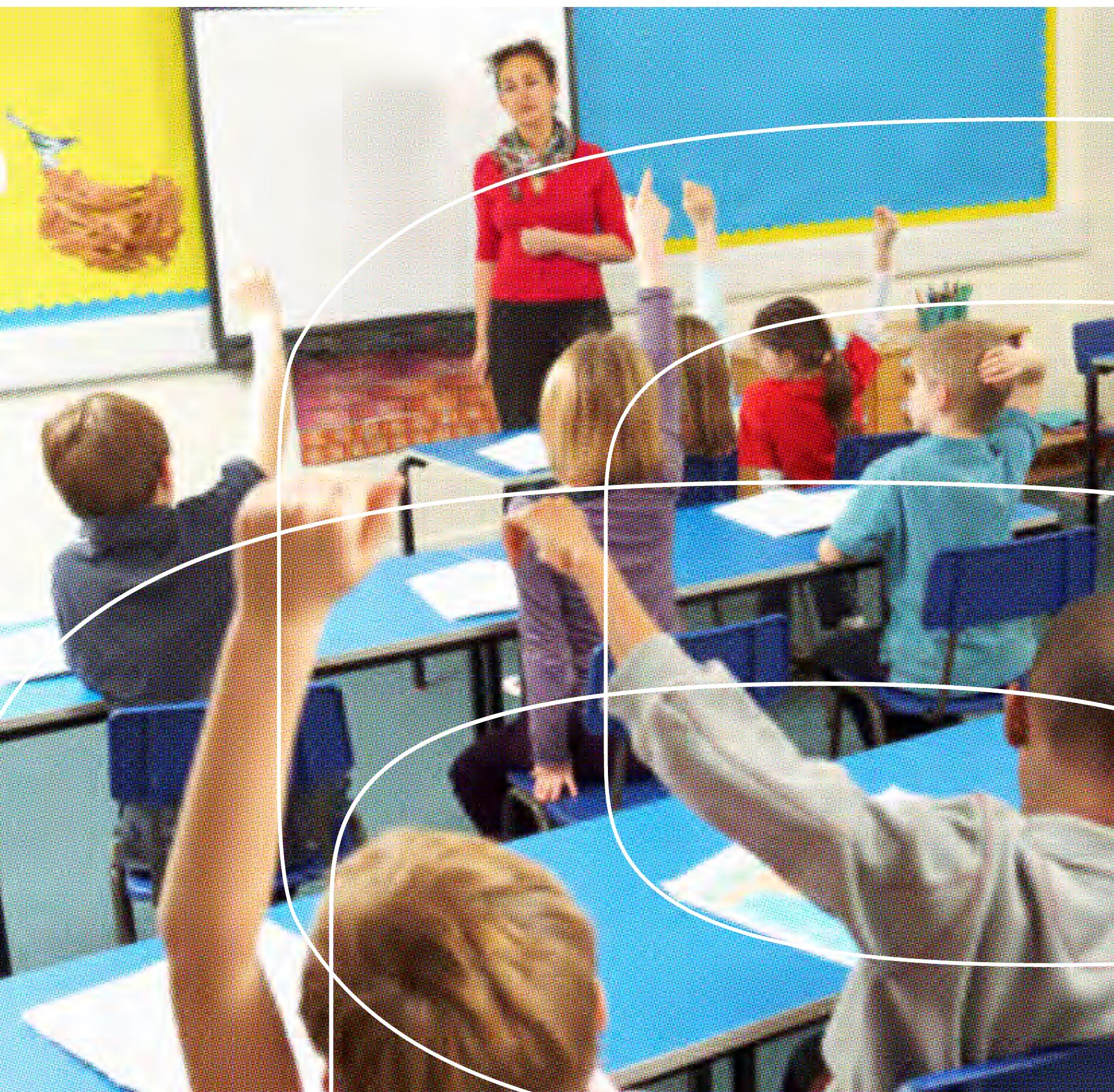


Gender mainstreaming in the work performed by municipalities

- Results and recommendations from a trans-Nordic study

ISBN 978-92-893-4096-0 (PDF)

http://dx.doi.org/10.6027/ANP2015-747

ANP 2015:747

(C) Nordic Council of Ministers 2015

Layout: Gitte Wejnold

Cover photo: SignElements.com

Photo: SignElements.com

Typeface: Meta LF

www.norden.org/da/publikationer

\section{Nordic co-operation}

Nordic co-operation is one of the world's most extensive forms of regional collaboration, involving Denmark, Finland, Iceland, Norway, Sweden, and the Faroe Islands, Greenland, and Åland.

Nordic co-operation has firm traditions in politics, the economy, and culture. It plays an important role in European and international collaboration, and aims at creating a strong Nordic community in a strong Europe.

Nordic co-operation seeks to safeguard Nordic and regional interests and principles in the global community. Common Nordic values help the region solidify its position as one of the world's most innovative and competitive.

\section{Nordic Council of Ministers}

Ved Stranden 18

DK-1061 Copenhagen $\mathrm{K}$

Telefon (+45) 33960200

www.norden.org 


\section{GENDER MAINSTREAMING IN THE WORK PERFORMED BY MUNICIPALITIES}

- Results and recommendations from a trans-Nordic study 



\section{CONTENTS}

GENDER EQUALITY IN A TRANS-NORDIC CONTEXT

BENEFITS OF GENDER MAINSTREAMING

RECOMMENDATIONS FOR THE APPLICATION

OF GENDER MAINSTREAMING

1.1.1 Holistic versus problem-oriented approach

1.1.2 Politically initiated/management-initiated versus trailblazers

1.1.3 Verbalisation and legitimacy

1.1.4 Focus on gender equality versus focus on diversity 20

1.1.5 Resources and procedures/tools

1.1.6 Documentation 


\section{GENDER EQUALITY \\ IN A TRANS-NORDIC CONTEXT}

\section{WHAT IS GENDER MAINSTREAMING?}

The concept of gender mainstreaming is a method, which incorporates a gender and gender equality perspective into public administration and planning, where gender may be of significance. It is about making policy decisions and preparing core services on an informed basis as well on the basis of the awareness, that gender is a factor that is important in all policy areas.

When gender equality is incorporated into legislation and activities, focus is on whether any differences between genders in a given discipline give rise to special measures or to a need for a different design of measures to reach the relevant target group. It will often be necessary to link gender with other parameters such as education, marital status, ethnicity and age in order to paint a picture that sufficiently illustrates the target group and thus obtain a basis for targeting measures, etc.

The concept of "ligestillingsvurdering" is used in Denmark. The other Nordic countries apply the concepts of "Integrering av könsperspektiv/ Jämstallhetsintegrering” (Finland), "Kynjasampætting/kønsintegrering" (Island), "Sektoransvar for integrering av kjønnslikestilling" (Norge) og “Jämstallhetsintegrering” (Sweden).
THE NORDIC COUNTRIES are generally characterised by a comprehensive focus on gender equality and have historically had a high degree of equality between women and men as well as girls and boys compared with other countries. This is true in the educational system, the labour market, the political system and society at large. This is also reflected in the fact that the Nordic countries are high up on the "Global Gender Gap Index", where Iceland, e.g., has been number one for five consecutive years ${ }^{1}$. Even though the Nordic countries rank high in international comparisons of gender equality, it is still important to focus on strengthening gender equality/gender mainstreaming work as women and men have different needs and behaviour, which may affect their possibilities of exploiting their resources in full in society and in their daily lives.

This booklet focuses on the results of a study of gender mainstreaming of core services at the municipal level in the Nordic countries. The study was launched by the Danish Ministry of Children, Gender Equality, Integration and Social Affairs to obtain knowledge about how public authorities apply gender mainstreaming in terms of policy areas and core services in practice. The study received financial support from the Nordic Council of Ministers. Oxford Research has conducted the study.

The study is based on 21 cases of good practice examples of how 


\section{CORE SERVICES IN THE PUBLIC SECTOR}

The concept core services covers the services the public sector provides for citizens. Core services in the public sector cover mainly specialized tasks such as:

- Preventive health care

- Building and maintenance of bike lanes

- Distribution of cultural grants

- Service of nursing homes

- Child care

- Public transport and road maintenance

- Public employment services

- Educational activities

gender mainstreaming has been applied to municipal core services ${ }^{2}$. Focus is on how gender and gender equality can be incorporated into the services targeting citizens by applying the gender mainstreaming method and on what results and effects this might have.

On this basis, inspiration and recommendations are provided for how municipalities can best work with gender mainstreaming. The objective is to inspire decisionmakers as well as practitioners to boost focus on gender equality and gender mainstreaming of citizenrelated core services and citizenoriented measures.

The booklet first gives a description of what the concept of gender mainstreaming means ${ }^{3}$. Next, it describes the overall results and effects of the study, and, finally, it lists examples of the work with gender mainstreaming of core services and recommendations for how to approach this work.
${ }^{1}$ The World Economic Forum, 2013, The Global Gender Gap Report 2013

${ }^{2}$ See more under Further information, back page. ${ }^{3}$ In all Nordic countries gender mainstreaming is defined according to the Council of Europe's definition of gender main-streaming, see http://www.coe.int/t/ dghl/standardsetting/equality/03themes/gendermainstreaming/index_en.asp 


\section{BENEFITS OF GENDER MAINSTREAMING}

The study shows that municipalities achieve both results and effects when applying gender mainstreaming. Moreover, the municipalities may achieve results in the form of increased core service quality, resource optimisation and changes in attitude and behaviour. The study also shows that these results lead to greater gender equality (effect).

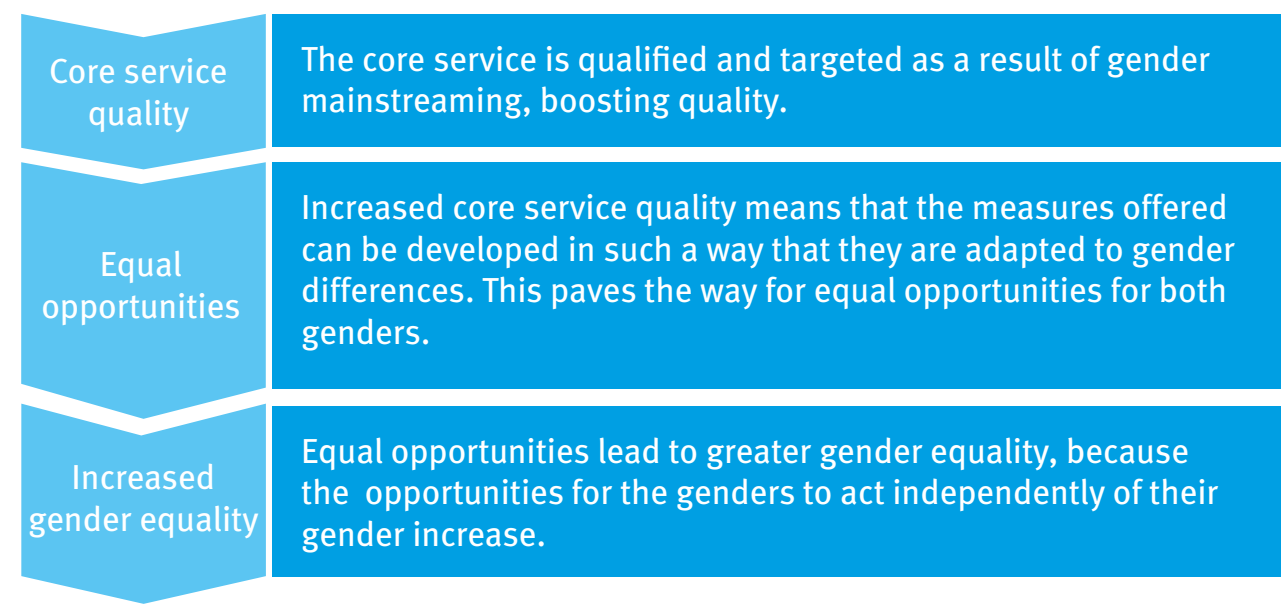

THE STUDY SHOWS that the above results and effects can be achieved if the following criteria are met:

- Resources are set aside for the application of gender mainstreaming

- Fixed procedures and tools for gender mainstreaming are prepared

- Legitimacy in relation to gender and gender equality is created, e.g. by verbalising gender equality and gender

- Gender equality and gender are verbalised to create legitimacy as well as an awareness of gender equality and gender

- A diversity perspective is included to ensure that factors other than gender are not overlooked

- Objectives and indicators of results and effects in relation to gender and gender equality are established

- Results and effects in relation to gender equality are documented.

The study shows that significant differences exist in the approach to gender mainstreaming across the Nordic countries. The differences are related to national contexts, including both political, economic and cultural conditions that affect the application of gender mainstreaming in the Nordic countries.

Denmark primarily takes on a problem-oriented approach, meaning that a burning platform is used - a concrete problem for a particular group of citizens, which is to be solved. This means that 


\section{Greater gender equality calls for both proactive and reactive measures}

measures in Denmark are reactive rather than preventive.

Sweden employs more holistic measures, many of which are of a preventive nature as changes in attitude and behaviour are considered. Focusing on changes in attitudes and behaviour creates a more long-term effect.

Norway has holistic programmes in selected areas, while Finland has introduced holistic programmes in selected municipalities. On a general level, work is being undertaken on the basis of a problem-oriented approach in both Finland and Norway.

Oxford Research finds that one approach is not necessarily "better" than the other. It is possible to achieve results and effects by applying either approach. The key point is that awareness exists whether the approach is problemoriented or holistic.
To change inequality between the genders, it is essential to launch both proactive and reactive measures as prevention can change the situation in the longer term, and reactive measures can address current inequality problems and thus create results in the short term. 


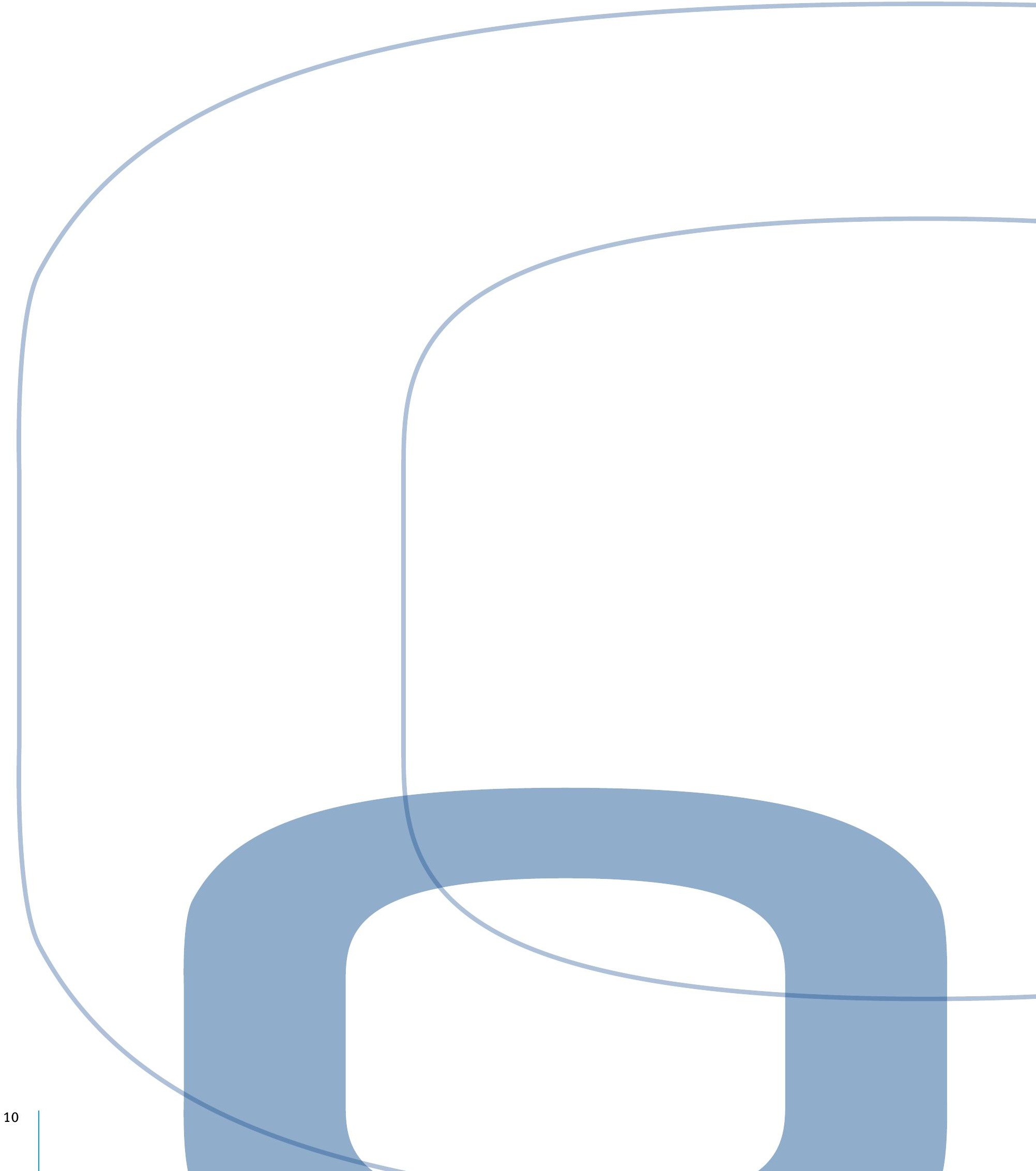




\section{RECOMMENDATIONS FOR THE APPLICATION OF GENDER MAINSTREAMING}

Recommendations for and concrete examples of how gender mainstreaming has been and can be applied are presented in the following. The concrete examples are good practice examples of how different municipalities conduct gender mainstreaming. 


\subsection{1 \\ HOLISTIC VERSUS PROBLEM- ORIENTED APPROACH}

Thinking along problem-oriented lines creates targeted measures, which means that concrete problems for specific groups of citizens are addressed. This approach can help the group of citizens in question by, for example, offering them more opportunities and greater room for manoeuvre. The result is that the target group will enjoy more equal footing with other citizens.

Adopting a more holistic approach creates more changes in attitude and behaviour with a more proactive focus. This changes the attitude towards gender equality and legitimacy as gender equality is ensured because it has political support and focus. Working with a problem-oriented approach thus primarily generates results in the short term, while the holistic approach focuses more on longterm effects in relation to gender equality. The two approaches are characterised by the following elements:

\section{Holistic approach}

- Gender mainstreaming takes place in several areas or at several levels: At the general political level and/or administration level

- Internal focus on employees and external focus on citizens in gender equality work

- Strong management focus and an explicit and strategic approach to gender mainstreaming

- Legitimacy and verbalisation of gender equality

- Top-down approach, which is given high priority in the organisation

- Allocation of resources and support for the employees

- The approach is characterised by systematics

- Focus on embedding new procedures, routines and tools

- Ongoing documentation of measures

\section{Problem-oriented approach}

- The starting point is a specific problem that needs to be solved

- Target group analysis with gender as a central factor

- Gender equality is not a goal in itself

- Alternative verbalisation of gender equality, e.g. diversity

- Lack of legitimacy of the gender equality perspective

- Gender mainstreaming is a pragmatic approach

- Gender equality perspective is initiated by trailblazers

- Bottom-up approach to gender mainstreaming

- Resources and support are limited or nonexistent

- Measures are project-based

- No focus on embedding and documentation 
Specifically in relation to the two approaches, the recommendations are as follows:

- the context should be incorporated when measures are initiated, e.g. in relation to available resources and how measures are to be verbalised to motivate both employees and citizens; and

- both holistic and problemoriented measures should be initiated since both types, i.e. proactive and reactive, are necessary to increase gender equality. In this context, it is essential to be aware of the type of measure initiated and the results and effects that can thus realistically be expected.

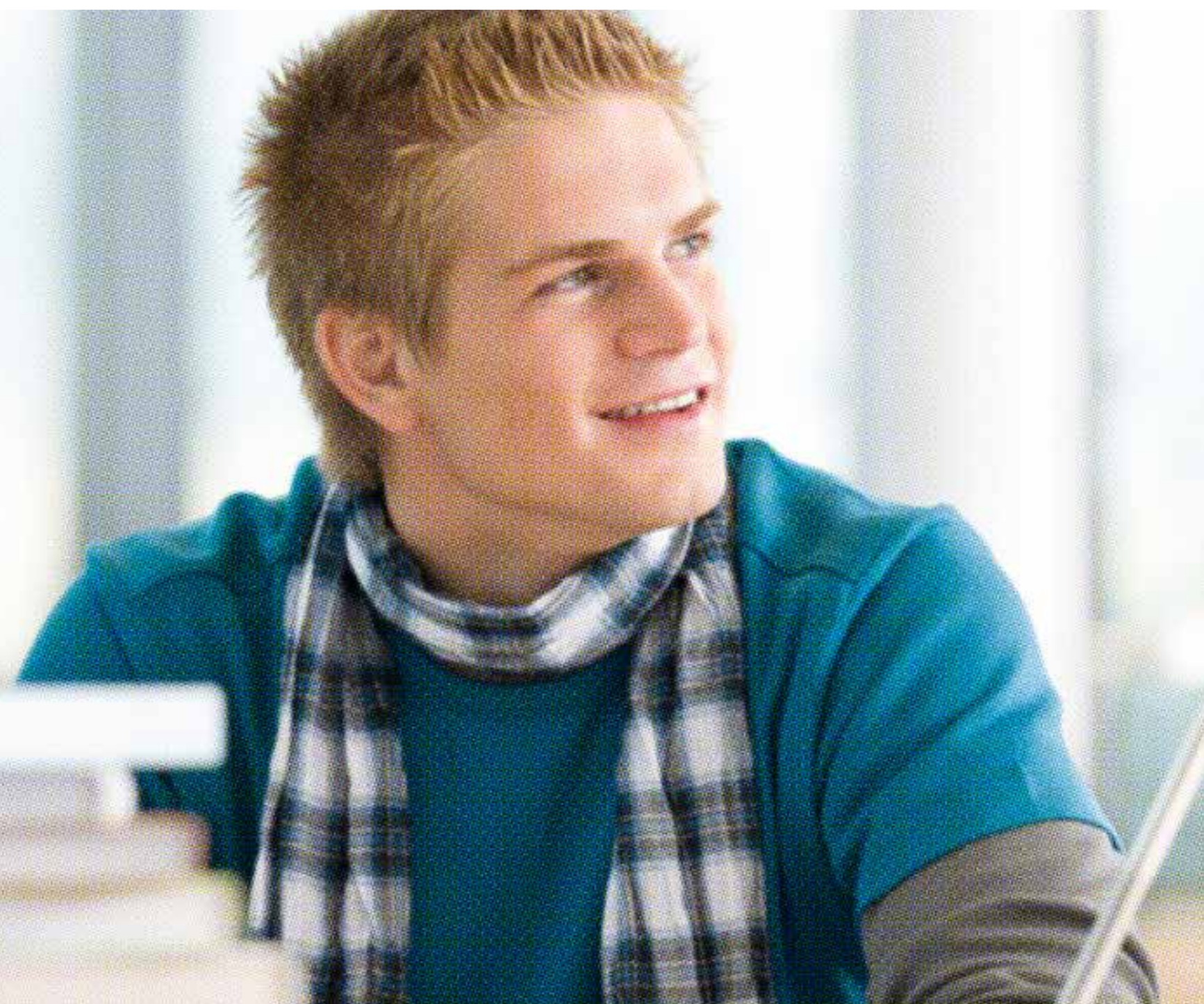




\subsection{2}

\section{POLITICALLY INITIATED/MANAGEMENT -INITIATED VERSUS TRAILBLAZERS}

A political, strategic approach creates legitimacy in relation to measures and the use of resources in the measures, because it has been given priority and decided upon by politicians.

The management-initiated approach has the advantage of having management support for gender equality focus in the measures or the gender equality-promoting initiative, which makes it easier for employees to allocate time and resources to the measures.

Measures initiated by trailblazers are those where employees and/ or managers are committed and motivated in improving gender equality in their work, but they also make measures vulnerable because they depend on few players.
The following examples of good practice demonstrate politically initiated/management-initiated measures and measures initiated by trailblazers.

\section{In relation to measures initiated} by politicians/management or trailblazers, the recommendations are as follows:

- both employees and managers should be involved and engaged in the measures to make them less vulnerable to staff and management replacements;

- both managers and employees should be trained to carry out gender analyses as the first step in applying gender mainstreaming as it requires specific qualifications to carry out gender analyses;
- both managers and employees should be trained in gender equality and gender mainstreaming as specific qualifications are required to conduct gender mainstreaming, and the application of this work becomes more meaningful for the employee/ manager if he or she has acquired a certain understanding of gender equality in general; and

- training in gender analyses, gender equality and gender mainstreaming should be handled by players with knowledge of both gender equality and local authority work to ensure that the gender equality work is included in a local context. 


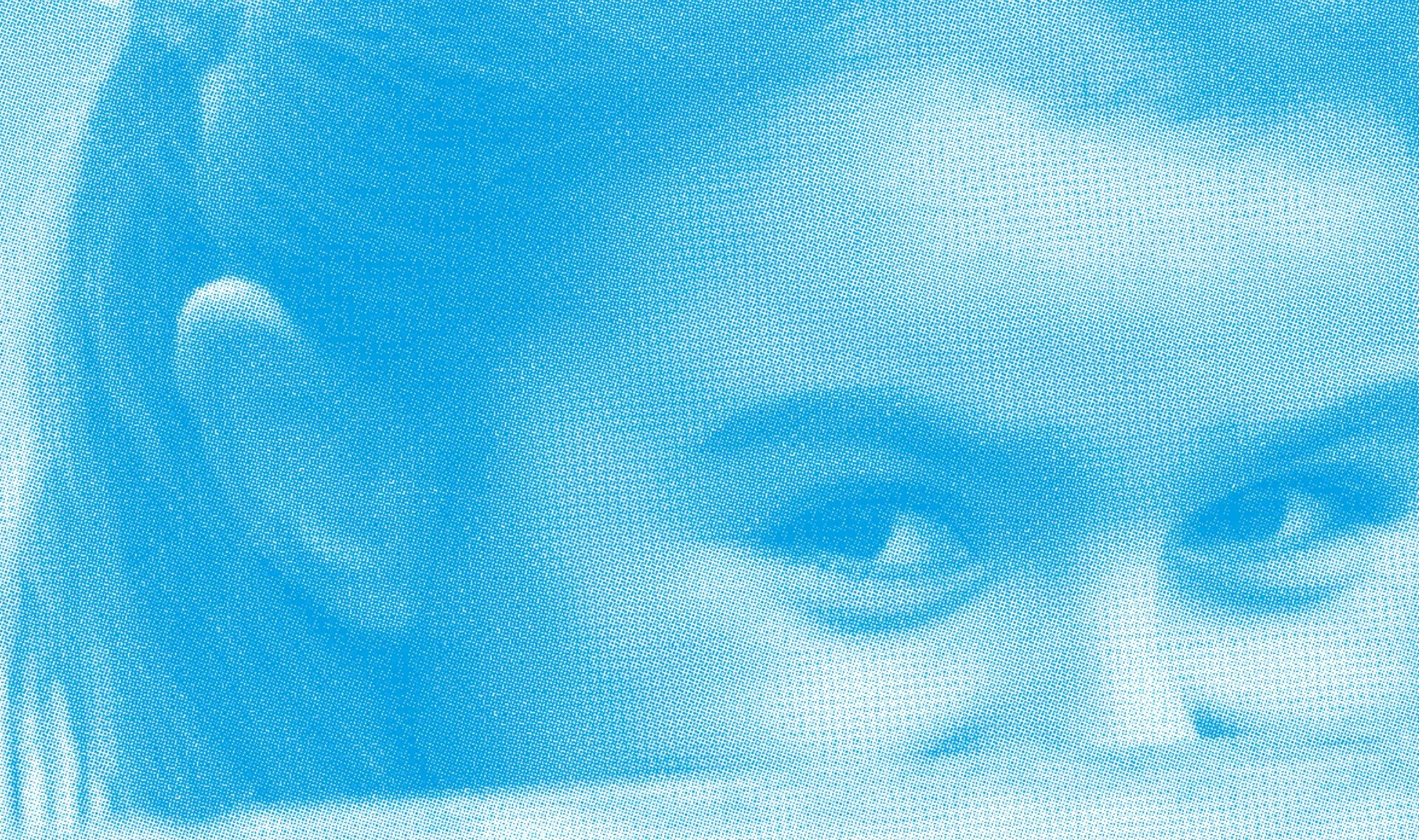

\section{EXAMPLE OF GOOD PRACTICE - INITIATED BY TRAILBLAZERS}

The kindergarten Violen in Örebro municipality in Sweden has been working with procedures and routines to improve gender equality. The gender equality work was initiated by two childhood educators, because they had a great interest in gender and gender equality. The educators hold the responsibility for running the process of embedding gender equality in the educational work, which has created ownership amoung the childhood educators. In this way, the work is more embedded in the childhood educators' daily practice and working methods. Management meets and spars with the child-hood educators, but is not directly involved in the implementation of the measures. Even though management is not directly involved in or holds responsibility for the measures, the strong management support has been very significant to the legitimisation of the measures.

The measures fall into three phases: Phase 1 included a literature study, a fact-finding visit to other kindergartens focusing on gender equality, gender-equality presentations and training in gender equality perspectives for employees. This was initiated to ensure that the employees were able to work in a qualified manner with gender equality work. Phase 2 involved video recordings of daily situations in the kindergarten with a subsequent analysis from a gender perspective and educational considerations. Phase 3 consisted of changes in practice and working methods to create a change in the behaviour of children from a gender equality perspective. 


\section{EXAMPLE OF GOOD PRACTICE - POLITICALLY INITIATED/MANAGEMENT-INITIATED}

For the past 10 years, the City of Vantaa in Finland has been working with gender equality and decided in 2009 that gender mainstreaming should be conducted in all administrative areas in the municipality. In relation to that, a project was launched to develop a model for the municipality's youth measures for the unemployed. Cooperation was established between the job centre and the social insurance institution, which was soon able to help the young people from unemployment into employment, training, education or other paths. This measure thus formed part of a politically initiated focus, and financial resources and staff resources have been set aside for the measure.

One result of the measure is the inclusion of a section in the employees' work descriptions on incorporation of gender in relation to counselling of young people and specific tools for how to integrate a gender perspective in general into both project and operational tasks. During the period 2010-2013, 821 new jobs were created and counselling was offered to 3,864 young people, who received a higher degree of individual and targeted counselling thanks to the focus on the gender aspect. This approach has also contributed to boosting the young people's confidence in the public system. In addition, 244 young people have enrolled in a further education programme and 213 companies took part in the cooperation. 



\subsection{3}

\section{VERBALISATION AND LEGITIMACY}

The study shows that it is essential to discuss the gender/gender equality perspective in the measures initiated. A continuing discussion of the gender/gender equality perspective means that the approach to the measures is qualified in tandem with the development of the measures and the maintenance of gender/ gender equality perspective in the measures.

The study shows that a difference exists between the legitimacy of gender equality verbalisation in the various Nordic countries, and it is important to be aware of the specific context and assess the degree to which gender equality should be verbalised in relation to the concrete measures.
The study also shows however, that external verbalisation of measures as a gender equality measure is, in the majority of cases, found to help create increased awareness of gender equality among citizens. Only in cases where citizens are excluded from participating in the measures, or where a risk of stigmatisation of certain groups exists, should the gender equality perspective be verbalised within the organization exclusively.

The example of good practice below shows how verbalisation of gender equality can contribute positively to creating core service quality.

In relation to gender equality verbalisation and legitimacy, the recommendations are as follows:
- it should be considered whether it is appropriate in relation to the relevant measures, to verbalise them as gender equality measures as this may lead to stigmatisation of citizens and/or prevent them from becoming involved in the measures;

- gender should be verbalised directly in the measures where appropriate so that focus on gender equality in society is created; and

- gender equality and gender should be verbalised internally in the organisation to qualify the gender/gender equality concept which underlies the work, and to create focus on gender equality and gender equality work. 


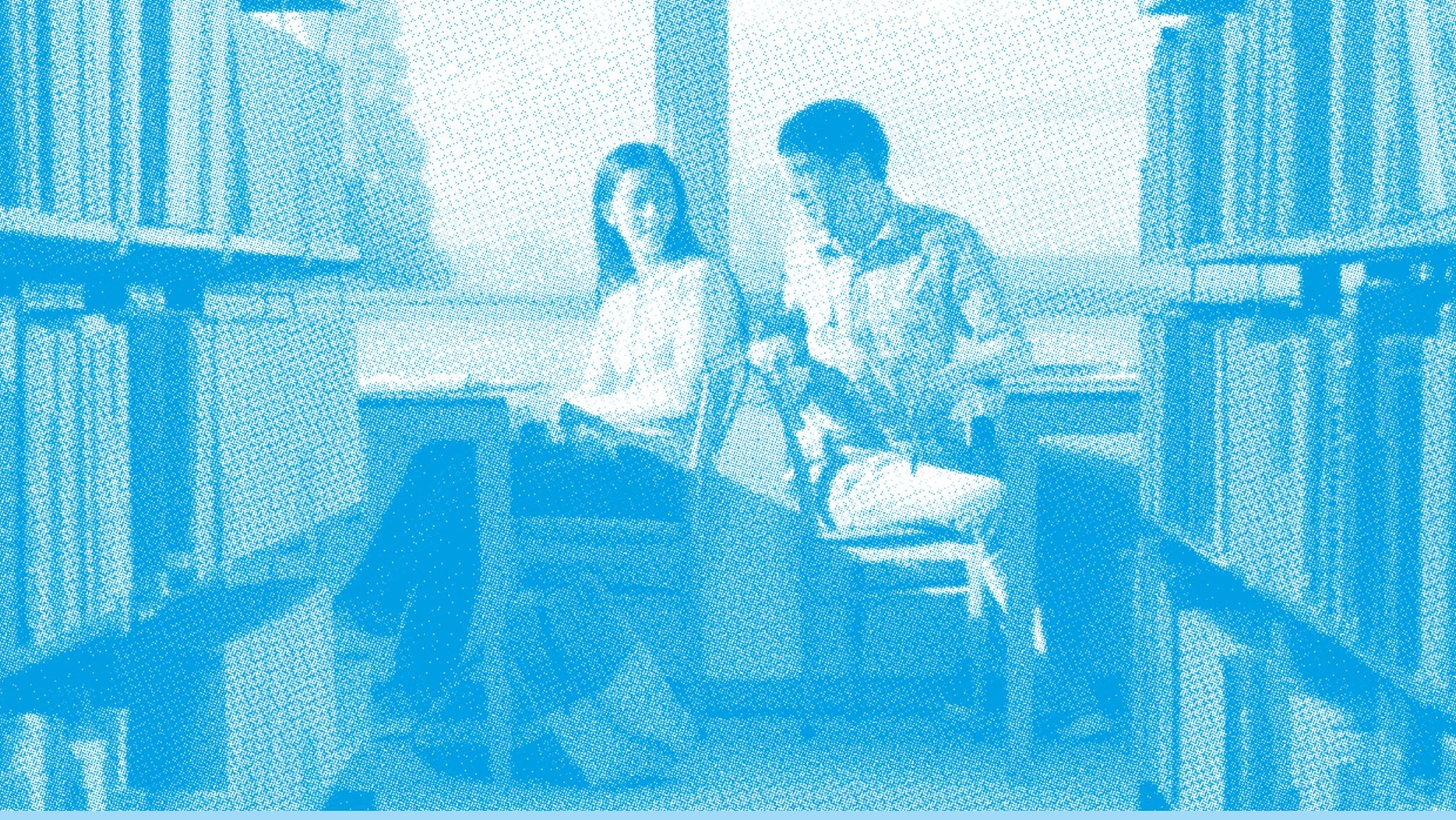

\section{EXAMPLE OF GOOD PRACTICE - VERBALISATION}

In recent years, Bleket upper level lower secondary school in Tjörn municipality in Sweden has been working explicitly with gender equality. The childhood educators at the school are driven by the idea of changing the terms and opportunities of boys and girls so that they have the same qualifications for having an education. Against this background, the school has prepared an action plan for gender equality work containing strategies, working methods and specific measures that can be applied. The aim is thus to increase gender equality and create equal opportunities. To achieve this the school has undertaken several measures. First, they ensured that selected employees received gender equality training. In addition, all the employees have conducted literature studies of gender theory to focus on gender equality and motivation for the measures. Moreover, the employees organise regular discussion groups to discuss gender-related practices, and how they may have to change their behaviour on this basis. Students are also directly involved in gender equality work, meaning that they will have a clearer understanding of gender equality.

The work has resulted in the preparation of a method manual with proposals for working methods as well as experience and results that can help embed measures when teachers or other staff are replaced. 


\subsection{4}

\section{FOCUS ON GENDER EQUALITY VERSUS FOCUS ON DIVERSITY}

The above shows an example of how emphasis on and verbalisation of gender equality can be beneficial for gender equality work and core service quality.

In order to create effects in relation to gender equality, particularly in a broader and more longterm perspective, the study thus indicates that it is necessary to work explicitly with gender equality for staff and management to be aware of inexpediencies in given measures.

The study shows that measures focusing on diversity are often based on target group analyses in which several factors, including education level, ethnicity, age and gender, are involved. Therefore, focus is placed on more factors than just gender. When focus is placed on several different factors, the gender equality perspective is at risk of fading into the background because these factors will be competing against one another. This means, for example, that it is more important to the development of measures that citizens are loweducated people or have a nonDanish background.

The following example reveals how in specific contexts, it may be relevant to refer to measures as diversity.

In relation to verbalisation of equality as gender equality or diversity, the recommendations are as follows:

- gender should be incorporated into all measures where gender is a factor of importance;
- it should be ensured that quantitative and/or qualitative studies are conducted of whether a gender perspective can change inappropriate behaviour and that this knowledge is included in the development of measures; and

- other inequality factors such as educational attainment, ethnicity and age should be involved in local measures to ensure that all relevant factors are allowed for. 


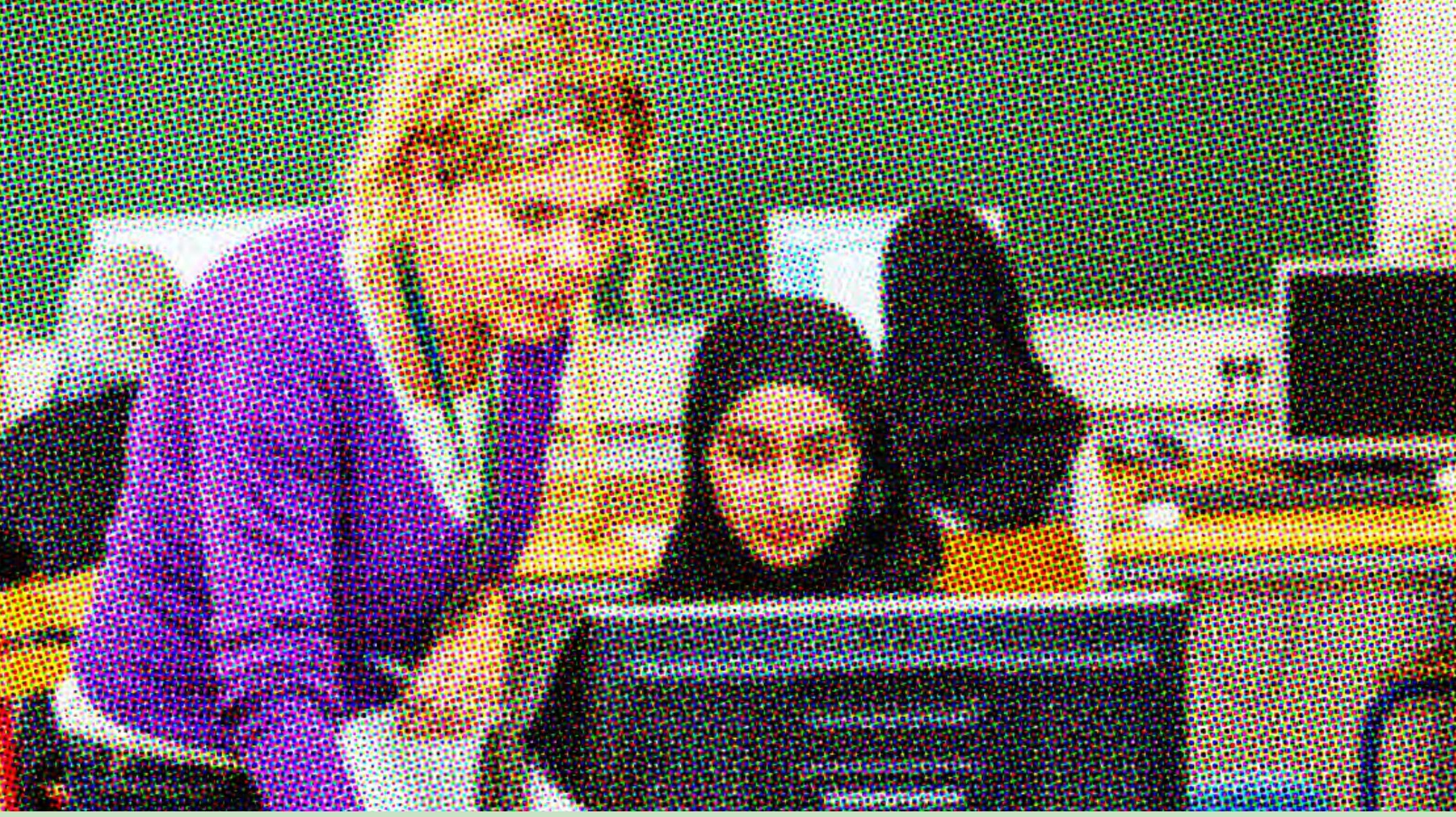

\section{EXAMPLE OF GOOD PRACTICE - DIVERSITY}

Project MI-x in Aarhus municipality in Denmark is a counselling programme for young women aged 18-29 with a non-Danish background. MI-x stands for diversity, integration and a personal $\mathrm{X}$-factor. The project objective is to increase integration of young people, low-educated women and women at risk of being excluded from the Danish labour market and the educational system.

The project has been developed on the basis of a target group analysis in which gender is one of the target group characteristics. The project contains obvious gender equality aspects in both the actual organisation of the measures and the work with the women, but the project is not referred to as a gender equality project, neither internally nor externally. Internally, the reason is that the employees define the project from a diversity and "equal opportunities for all" perspective. Externally, the verbalisation of gender equality may, according to the employees, hamper the target group's participation in the programme as it could potentially create problems in the women's support base, which often are already a part of the challenges the women face.

As a result of the project, the women have come one step closer to self-support, because they have increased their personal and academic competences and are better prepared in terms of having an education and entering the labour market. Moreover, the measures have meant that the women have found a new community with peers and experienced a sense of security. 


\subsection{5}

\section{RESOURCES AND PROCEDURES/TOOLS}

The study shows that the allocation of resources for gender mainstreaming increases core service quality.

The allocation of resources is key to creating focus on gender equality and maintaining this focus. This applies to financial resources allocated for gender equality work or allocation of man hours so that the work is given priority. It may also be beneficial to set aside resources for external support, which can advise and guide employees and managers of local municipalities in applying gender mainstreaming as they require specific competences.

Fixed procedures and development of gender equality work tools contribute to embedding measures and making it easier for employees and managers to work with gender equality because they have specific instruments to use.
The following example of good practice shows how resources, procedures and tools can contribute positively to creating core service quality.

In relation to resources, procedures and tools, the recommendations are as follows:

- funds should be allocated from the central government for the work of gender mainstreaming and the municipalities should give priority to the work by allocating man hours for it. This is recommended in conjunction with training specific managers and employees in applying gender main-streaming, as they work with core services where gender is a relevant factor;

- political and management support should be mustered for gender equality measures. This contributes to the creation of focus on the fact that gender equality is still an area of inequality;

- the local interest groups within municipalities in the Nordic countries should point out ways and methods for how the municipalities could work with gender mainstreaming. That means that previous experience should be brought up on an ongoing basis. In addition, the municipalities should be offered relevant support (sparring and advisory services) as they conduct gender equality work; and

- the municipalities should earmark resources for the development of local procedures for gender mainstreaming and resources for implementing already existing tools and methods. 


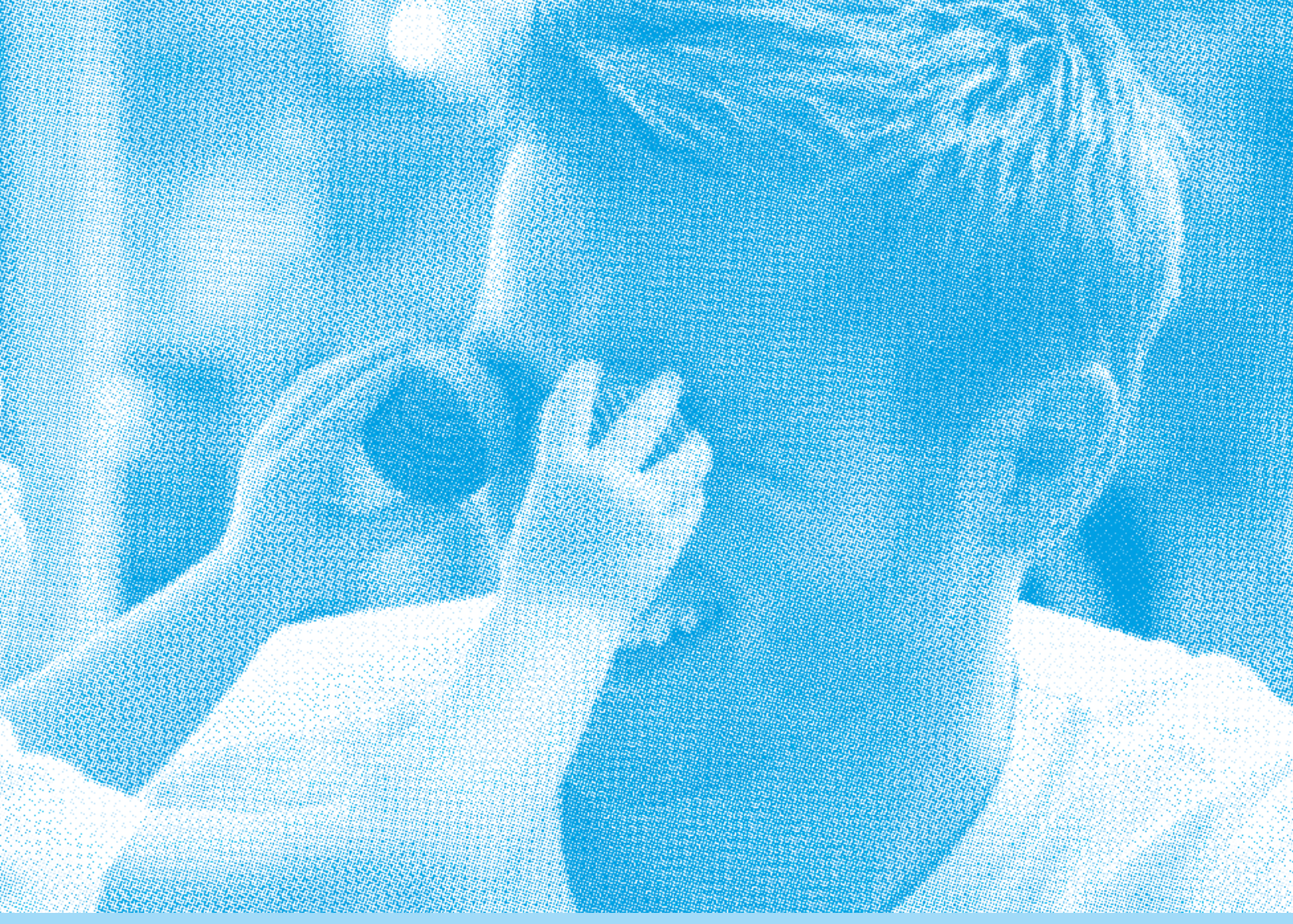

\section{EXAMPLE OF GOOD PRACTICE - RESOURCES AND TOOLS}

Kvinesdal municipality in Norway aims at increasing gender equality in its kindergartens and further develop their application of gender mainstreaming and assessments already seen in the kindergartens. Part of the programme is to increase the number of male kindergarten staff. A significant project prior to the current measures was a project where childhood educators filmed their interaction with the children, and the footage provided the basis for registering inappropriate behavioural patterns in the kindergarten. A gender equality kit has been developed, containing methods and tools for gender equality work in kindergartens. The kit contains tools for recruiting men for the kindergartens and staff-related tools as well as tools for the educational work with the children. These tools have helped the kindergartens implement more equal educational work.

Both external funds and local funds were allocated for the project, and thus it was possible to employ a project coordinator, equivalent to $10-20 \%$ of his/her working hours. The informants in this case find that it is essential to maintain continuity and to avoid having the project underpinned by trailblazers who may withdraw from it. 


\subsection{6}

\section{DOCUMENTATION}

Documentation is a method for rendering visible the effects of measures. Documentation can point out the results of measures, intended as well as unintended. Documentation is also of importance to a change process as it can help maintain focus on why the measures are beneficial and make sense. Documentation can also help maintain focus on gender equality over time.

To document results and effects on gender equality, it is important that specific objectives have been laid down and that measurable indicators in relation to gender equality have been assigned.
The example of good practice below shows a measure where gender equality objectives were laid down and where the results are documented.

\section{In relation to the use}

of documentation, the recommendations are as follows:

- objectives and measurable indicators for gender equality/ gender should be prepared to ensure that this is included in the documentation of the results and effects of the measure;

- the municipalities should allocate resources to document the results and effects of measures in terms of gender/gender equality. Demonstration of positive results/effects in the form of in-creased core service quality for example, has a highly motivational effect in relation to continuing gender equality work; and

- requirement should (still) be made for documentation of results and effects of gender equality when funds are allocated for the municipalities. 



\section{FURTHER INFORMATION}

For further information about the study and its results (in Danish), reference is made to the report Kortlægning af good practice og effekter i de offentlige myndigheders arbejde med ligestillingsvurdering på udvalgte serviceområder - kommunalt niveau. The report was drawn up by Oxford Research A/S, September 2014.
The study contains an analysis of municipalties' use of gender mainstreaming in Denmark, Finland, Norway and Sweden. The analysis is based partly on 21 good practice examples of gender mainstreaming of core services in Nordic municipalities and partly on a review of the political, legal, economic and cultural characteristics influencing the application of gender mainstreaming in the four Nordic countries (national contexts).

\section{DANMARK}

Oxford Research A/S

Falkoner Allé 20

2000 Frederiksberg

Danmark

Tel: (+45) 33691369

office@oxfordresearch.dk
NORGE

Oxford Research AS

Østre Strandgate 1

4610 Kristiansand

Norge

Tel: (+47) 40005793

post@oxford.no
SVERIGE

Oxford Research AB

Norrlandsgatan 11

10393 Stockholm

Sverige

Tel: (+46) 08240700

office@oxfordresearch.se
FINLAND

Oxford Research Oy

Helsinki:

Fredrikinkatu 61a, 6krs

00100 Helsinki, Suomi

www.oxfordresearch.fi

office@oxfordresearch.fi
BRUXELLES

Oxford Research

C/o ENSR

5. Rue Archiméde

Box 4, 1000 Brussels www.oxfordresearch.eu office@oxfordresearch.eu 

norden

Nordic Council of Ministers

Ved Stranden 18

DK-1061 København K

www.norden.org

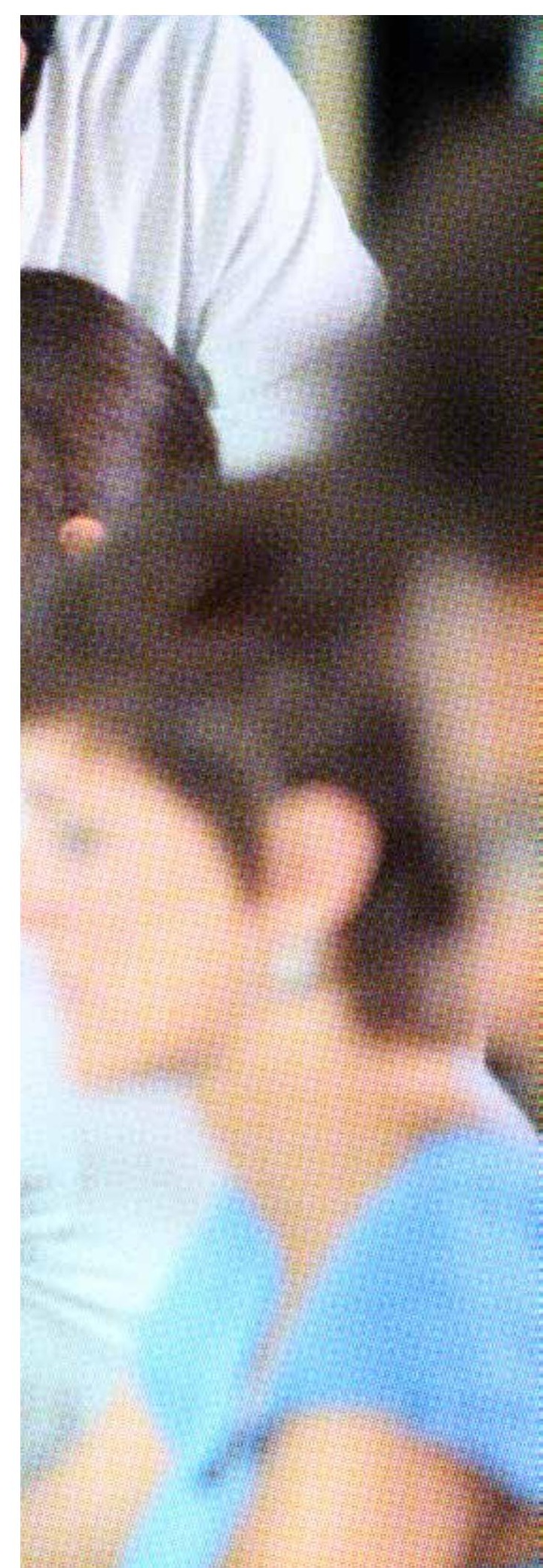

